\title{
Taxonomic Studies on Culex (Melanoconion) coppenamensis Bonne-Wepster \& Bonne (Diptera: Culicidae), and Description of Two New Species from Brazil
}

\begin{abstract}
Maria Anice Mureb Sallum/+ , Rosa Sá Gomes Hutchings*
Núcleo de Pesquisas Taxonômica e Sistemática em Entomologia Médica, Departamento de Epidemiologia, Faculdade de Saúde Pública, Universidade de São Paulo, Avenida Dr. Arnaldo 715, 01246-904 São Paulo, SP, Brasil *Coordenadoria de Pesquisas em Entomologia, Instituto de Pesquisas da Amazônia, Manaus, AM, Brasil

Two new species, Culex (Melanoconion) alinkios and Culex (Melanoconion) symbletos are described and defined based on morphological features of the male genitalia. The former is from Vale do Ribeira, Atlantic Forest, southeastern of the state of São Paulo, Brazil, and belongs to the Bastagarius subgroup. The latter is from the Parque Nacional do Jaú, state of Amazonas, Brazil, and belongs to the Inhibitator subgroup and is similar to Cx. mesodenticulatus Galindo and Mendez. Diagnostic characters for the identification of the adult males of the species are provided. Two morphological forms (Form 1 and 2), which are similar to Cx. coppenamensis, were also found in the Parque Nacional do Jaú. Form 1 is described and compared with the new species from Vale do Ribeira and Form 2.
\end{abstract}

Key words: Amazon basin - Parque Nacional do Jaú - Atlantic Forest - Culicidae - Culex (Melanoconion) - new species

During an entomological inventory carried out in the Parque Nacional do Jaú (Jaú National Park), state of Amazonas, Brazil, we collected several species of Culex (Melanoconion), including a few individuals which were identified as two distinct morphological forms similar to Cx. coppenamensis. Comparing those two forms with specimens collected in Vale do Ribeira, the Atlantic Forest, southeastern state of São Paulo, Brazil, several diagnostic morphological characters of the male genitalia were recognized and used to distinguish all three forms. Comparing male genitalia structures of the two Amazonian forms with drawings of specimens identified as $C x$. coppenamensis available in the literature (Pecor et al. 1992), we were unable to recognize which of those two Amazonian forms belongs to Cx. coppenamensis. However, the São Paulo form represents an undescribed species. Unfortunately, the diagnostic characters used to distinguish each $C x$. coppenamensis Amazonian form from Cx. coppenamensis are not clear in Bonne-Wepster and Bonne's (1925) male genitalia drawing. However, it seems that one of the Amazonian forms (hereafter named Form 1) may be a new species. The second Amazonian

The specimens from the Parque Nacional do Jaú were collected using resources from the Instituto Nacional de Pesquisas da Amazônia (Inpa PPI-3400/1995) and Fundação Vitória Amazônica (Projeto Levantamento da Entomofauna do Parque Nacional do Jaú, Amazonas Convênio Inpa/FVA). MAMS was supported by Fundação de Amparo à Pesquisa do Estado de São Paulo (Fapesp), São Paulo, Brasil (grants 2001/03283-6 and 1999/10517-1).

${ }^{+}$Corresponding author. Fax: +55-11-3282.1898. E-mail: masallum@usp.br

Received 8 January 2003

Accepted 25 June 2003 form (Form 2) appears to belong to Cx. coppenamensis, based on the gonostylus and seta 1 of the distal division of the subapical lobe of the gonocoxite. Since there are only three male genitalia and two pinned adults of the Amazonian Form 2 available for study, it is difficult to define if Form 2 represents a new species or a variant of $C x$. coppenamensis. In fact, there is one specimen from French Guyana, deposited at the Faculdade de Saúde Pública Entomological Collection (FSP-USP), identified by Floch as $C x$. coppenamensis, which is similar to Cx. coppenamensis Form 2. The specimen designated as lectotype of $C x$. coppenamensis by Belkin (1968) is part of the Bonne-Wepster and Bonne collection, which is deposited at the National Museum of Natural Histoty Naturalis (RNHM) in Leiden, The Netherlands. Unfortunately, we had access only to the adult male but not to the microscope slide with male genitalia of the lectotype. For this reason, we were unable to recognize which of the two Amazonian forms belongs, in fact, to $C x$. coppenamensis, especially because they are sympatric. In addition, specimens of another new species, which is morphologically similar to $C x$. mesodenticulatus were collected in the Parque Nacional do Jaú. In the present study, we describe two new species of the subgenus Melanoconion of Culex. We also compare and provide diagnostic characters to distinguish $C x$. coppenamensis Amazonian Forms 1 and 2 from the new species from the state of São Paulo.

\section{RESULTS \\ Culex (Melanoconion) coppenamensis Form 1} (Fig. 1)

Male - Body almost entirely covered with dark brown scales. Head: antenna dark, strongly verticillate, length $1.36-1.59 \mathrm{~mm}($ mean $=1.52 \mathrm{~mm} \pm 0.11)(\mathrm{n}=4)$. Proboscis entirely dark-scaled. Maxillary palpus dark-scaled, length $1.95-2.10 \mathrm{~mm}($ mean $=2.02 \mathrm{~mm} \pm 0.08)(\mathrm{n}=3)$, extending 
beyond proboscis tip by length of apical 0.7 of palpomere 4 and palpomere 5 , palpomeres 4 and 5 densely setose, palpomere 3 with 2, 3 strong setae on outer apical surface. Vertex with broad spatulate dark grayish scales, covered to some extent posteriorly from the ocular margin to occiput; erect forked scales numerous, scattered throughout vertex, entirely black; occipital region with few narrow, falcate, grayish scales. Thorax: integument brown with coppery sheen. Scutum covered with narrow, falcate scales uniform in size and color, scales dark brown with discrete reddish reflection. Scutal setae prominent, dark brown with reddish sheen; acrostichal setae absent. Scutellar scales similar to scutal scales; lateral lobes with three large setae each, median lobe with six setae. Antepronotum without scales, with scattered dark setae. Postpronotum with scales similar to scutal scales, with four setae on posterodorsal margin. Pleural integument median to dark brown, no pattern of pale and dark spots present. Pleural setae mostly dark brown with golden reflection, smallest lower mesokatepisternal setae light brown to golden: 6,7 upper proepisternal, 3,4 prealar, 5-7 upper mesokatepisternal, 7,8 lower mesokatepisternal, 37 upper mesepimeral and one lower mesepimeral. Pleura with scales on lower posterior margin of mesokatepisternum only. Integument of mesopostnotum of same color as scutum, entirely bare. Wing: dark-scaled; length $2.02-2.23 \mathrm{~mm}$ (mean $=2.14 \mathrm{~mm} \pm 0.08)(\mathrm{n}=5)$; cell $\mathrm{R}_{2}$ 3.16-3.92 of the vein $\mathrm{R}_{2+3}($ mean $=3.43 \pm 0.31)(\mathrm{n}=5)$; cell $\mathrm{M}_{2}$ 0.66-0.77 (mean $=0.69 \pm 0.05$ ) of cell $\mathrm{R}_{2}$; subcosta intersects costa at level of furcation of $\mathrm{R}_{2+3}$. Dorsal scaling consists of appressed spatulate scales on costa, subcosta, $\mathrm{R}$, proximal 0.5 of $\mathrm{R}_{3}, \mathrm{R}_{4+5}, \mathrm{Cu}, \mathrm{Cu}_{1}, \mathrm{Cu}_{2}$ and $1 \mathrm{~A}$; linear plume scales on $\mathrm{R}_{\mathrm{S}}, \mathrm{R}_{2+3}$ and $\mathrm{M}$; inclined narrow spatulate scales on $\mathrm{R}_{1}, \mathrm{R}_{2}$, distal 0.5 of $\mathrm{R}_{3}, \mathrm{M}_{1+2}$ and $\mathrm{M}_{3+4}$; remigium with appressed spatulate scales and 2 distal setae. Ventral scaling consists of appressed spatulate scales on costa, subcosta, $\mathrm{R}_{\mathrm{s}}, \mathrm{R}_{2+3}$, proximal end of $\mathrm{R}_{2}$ and of $\mathrm{R}_{3}, \mathrm{M}$, and proximal end of $\mathrm{M}_{1+2}$; linear plume scales on proximal 0.2 of $\mathrm{R}_{1}, \mathrm{Cu}_{1}$ and $\mathrm{Cu}_{2}$ inclined narrow spatulate scales on distal 0.8 of $\mathrm{R}_{1}, \mathrm{R}_{2}, \mathrm{R}_{3}, \mathrm{R}_{4+5}$, $\mathrm{M}_{1+2}, \mathrm{M}_{3+4}$ and distally on $1 \mathrm{~A} ; \mathrm{Cu}$ and proximal 0.8 of $1 \mathrm{~A}$ devoid of scales. Halter: scabellum and pedicel pale; capitellum dark-scaled. Legs: tibiae and tarsi entirely darkscaled. Abdomen: tergum I with a median posterior patch of dark scales; terga II-III entirely dark-scaled, terga IVVII mostly dark-scaled with small basolateral patches of whitish scales; tergum VIII (Fig. 1F) dark-scaled with basolateral patches of pale scales, with V-shaped emargination, forming two rounded lateral lobes distally. Sterna II-VIII mostly dark-scaled, sterna V-VII with small basolateral patches of whitish scales; sternum VIII darkscaled. Genitalia (Figs 1-2): tergum IX as figured (Fig. 1C). Gonocoxite globose, outer margin convex, inner margin nearly straight; ventrolateral setae strongly developed, ventromesal surface with small setae scattered from base to level of distal division of subapical lobe, setae stronger basally, lateral surface with a well developed patch of long, slender setae (lsp) at level of subapical lobe (Fig. 1A); tergomesal surface with 2-5 foliform setae at level of subapical lobe (Fig. 1B); proximal part of ventrolateral surface with scales (Fig. 1A); subapical lobe distinctly divided, divisions separated, proximal division unique at base, columnar, not clearly divided into two branches at apex, proximal branch shorter than distal branch, each branch bearing 1 long, robust, sinuous, apically hooked seta (setae $a$ and $b$ ), seta $b$ stronger than $a$, proximal division with a patch of short setae mesally at base of distal surface (Figs 1A, B); distal division divided into two arms, a proximal, relatively short and broad arm and a long, strong columnar arm arising from base at lateral surface (Figs 1A, B). Most proximal arm with six apical setae, including one long, strong, apically hooked seta (h) and one relatively long, narrow, pointed saberlike seta (s) inserted in a small tubercle at base of $h$ seta, both $h$ and $s$ arise from separate tubercles at proximal side of arm, separate from remaining setae, and three subequal, narrow appressed foliform setae (f) and one long, strong, saberlike seta (s) inserted at distal side. Columnar arm (Figs 1A, B) long, strong, nearly straight with one foliform seta (1) arising from apex; foliform seta (1) strongly enlarged, asymmetrical not striate with a well developed lobe projecting distally from the apex (Figs 1A, B). Gonostylus (Figs 1A, B) short, strong, curved at midlength, with a patch of spicules at midlength on dorsal surface, widened at distal 0.5 on lateral view tapering to apex and bearing a crest of short, scattered spicules extending distally from widened part to apex of apical snout on ventral surface; apical snout short; gonostylar claw short, leaflike. Phallosome (Fig. 1E) with lateral plate slightly longer than aedeagal sclerite, aedeagal sclerite narrow and curved in lateral view with anterior margin tickened and sclerotized, distal end narrowly fused to base of lateral plate; distal part of lateral plate with apical, ventral and lateral processes; apical process short, broad at base, somewhat curved on ventral side, apical margin straight and smooth, pointed at dorsal side, dorsal edge concave; ventral process short, somewhat hooklike, pointed, curved laterally; lateral process elongate, somewhat triangular, dorsolaterally directed, tapering to apex, apex pointed; base of lateral plate with short dorsal process and basally continuous with thickened margin of aedeagal sclerite. Aedeagal sclerite not connected by dorsal aedeagal bridge. Proctiger (Fig. 1D) elongate; paraproct distally narrowed, basally expanded at articulation with basal plate and posterolateral margin of tergum $\mathrm{X}$; paraproct crown with 9-10 simple blades; 2, 3 cercal setae. Tergum X (Fig. 1D) large, somewhat rectangular in outline, rounded at apex; medial surface convex, widened distally projecting in a distal lobe.

Material examined - Cx. coppenamensis Form 1: 54 specimens ( 25 pinned adult males, 2 adult males mounted on microscope slides, 27 male genitalia on microscope slides), BRAZIL: state of Amazonas, Novo Airão County, Parque Nacional do Jaú, Miratuca River ( $1^{\circ} 47^{\prime} 2^{\prime}$ 'S and 61'49' '1'W), 26 July 1995, 8:00 pm-9:00 pm, collected in Shannon trap inside tropical rain forest, Sallum \& Hutchings coll., 1 male, 1 male genitalia; same data except for Carabinani River ( $1^{\circ} 59^{\prime} \mathrm{S}$ and $\left.61^{\circ} 32^{\prime} \mathrm{W}\right), 12-13$ April 1994, Ferreira \& Hutchings coll., CDC light trap, 2 male, 2 male genitalia; ( ${ }^{\circ} 1$ '36"S and 61 ${ }^{\circ} 32$ '22'W), 28 July 1995 , 6:00 pm-8:00 pm, 1 male, 1 male genitalia; Miratuca River (1'47'2"'S and 61' $49^{\prime}{ }^{\prime}$ '”'W), 26, 27 July 1995, 6:00 pm-6:00 am, collected in UV light trap, RW Hutchings coll., 15 
males, 15 male genitalia, 2 adult males mounted on microscope slides with associated dissected male genitalia; 28, 29 July 1995, 5 males, 5 male genitalia; 26 July 1995, 7:00 pm-8:00 pm, collected in Shannon trap inside forest, Hutchings \& Sallum coll., 1 male, 1 male genitalia. OTHER MATERIAL: $C x$. coppenamensis Form 2 (Fig. 2): five specimens ( 2 pinned adult males, 3 male genitalia on microscope slides), as follows: FRENCH GUYANA: Gare Tigre Forest, H. Floch coll., October 1945, H. Floch det., September 1946, FSP-USP Acc \# 6330, 1 male genitalia; BRAZIL: state of Amazonas, Novo Airão County, Parque Nacional do Jaú, Miratuca River (147’2”S and
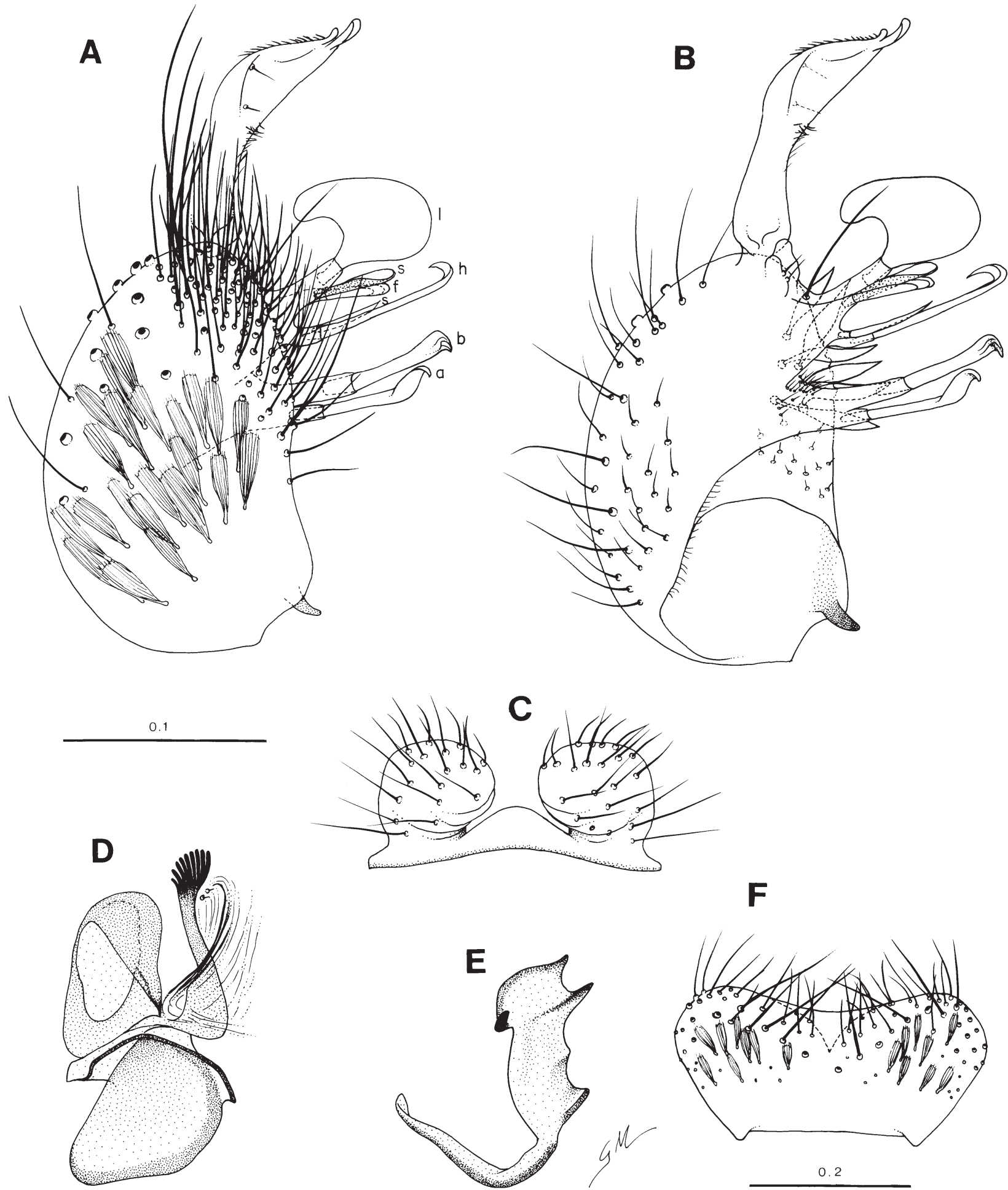

\section{$\mathbf{F}$}
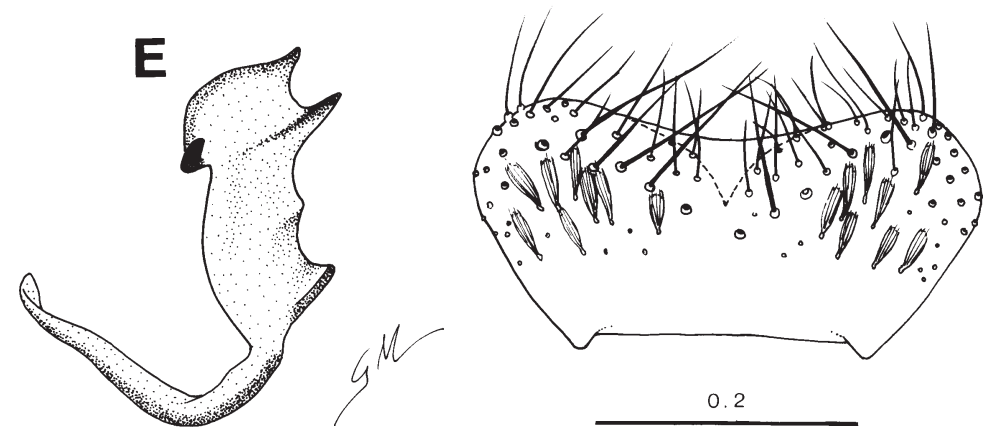

Fig. 1: male genitalia structures of Culex coppenamensis Form 1. A: gonocoxite and gonostylus in lateral aspect; B: gonocoxite and gonostylus in mesal aspect; C: tergum IX in dorsal aspect; D: proctiger; E: lateral plate and aedeagal sclerite in lateral aspect; F: tergum VIII in dorsal aspect. Scales in $\mathrm{mm}$ 
61\%49'1'W), 26, 27 July 1995, 6:00 pm-6:00 am, collected in UV light trap, RW Hutchings coll., 2 males, 2 male genitalia (Fig. 2).

Distribution and bionomics - Cx. coppenamensis Form 1 is known from the Parque Nacional do Jaú, Novo Airão County, state of Amazonas, Brazil. Nothing is known about the medical importance and bionomics of this form.

\section{Culex (Melanoconion) alinkios, n. sp.} (Fig. 3)

Male - Similar to Cx. coppenamensis Form 1, but differing as follows. Head: antennal length 1.64-1.81 mm $($ mean $=1.74 \pm 0.07)(n=5)$. Maxillary palpus length 2.20 $2.51 \mathrm{~mm}($ mean $=2.33 \pm 0.14)(\mathrm{n}=5)$; palpomere 3 with $2-4$ strong setae on outer apical surface. Thorax: postpronotum with 3, 4 setae on posterodorsal margin. Pleural setae: 5-8 upper proepisternal, 2-4 prealar, 6-8 upper mesokatepisternal, 6-9 lower mesokatepisternal and 5-7 upper mesepimeral. Wing: length 2.45-2.87 $\mathrm{mm}($ mean $=$ $2.60 \mathrm{~mm} \pm 0.16)(\mathrm{n}=5)$; cell $\mathrm{R}_{2} 3.04-4.27$ of vein $\mathrm{R}_{2+3}$ (mean $=3.71 \pm 0.47)(\mathrm{n}=5)$; cell $\mathrm{M}_{2} 0.67-0.72$ of cell $\mathrm{R}_{2}($ mean $=$ $0.69 \pm 0.02)(n=5)$. Abdomen: tergum VIII (Fig. 3D) with deep V-shaped emargination, forming two somewhat triangular lateral lobes. Genitalia: tergum IX as figured (Fig. 3C); tergomesal surface of gonocoxite with slender setae extending from base to level of subapical lobe; subapical lobe (Fig. 3B) distinctly divided, divisions separated, proximal division unique at base, columnar, not clearly divided into two branches at apex, proximal branch shorter than distal branch, each branch bearing one long, robust, sinuous, apically hooked seta (setae a and b), seta b stronger than a, proximal division with a patch of short setae mesally at base of distal surface; distal division (Fig. 3B) divided into two arms, a proximal broad and short arm, and a long, strong, curved columnar arm arising distally from base of distal division. Most proximal arm with six apical setae, including one long, strong, apically hooked seta $(\mathrm{h})$ and one relatively long, sinuous, narrow, truncate at apex saberlike setae (s), both setae (h and s) inserted at proximal side; one long, strong saberlike seta (s) and three subequal, foliform, narrow appressed foliform setae (f) arising from distal side. Distal curved arm (Fig. 3B) with an enlarged, asymmetrical basally striated seta (1) at apex, one seta with a beaklike projection at base of distal edge, proximal edge irregular. Gonostylus (Fig. 3A) short, strong, curved at midlength with a patch of spicules arising from dorsal surface, gonostylus widened at basal 0.5 in lateral view, tapering to apex and bearing a crest of short, scattered spicules extending from widened part to apex of apical snout on ventral surface; apical snout short; gonostylar claw short, leaflike. Paraproct crown with 10-
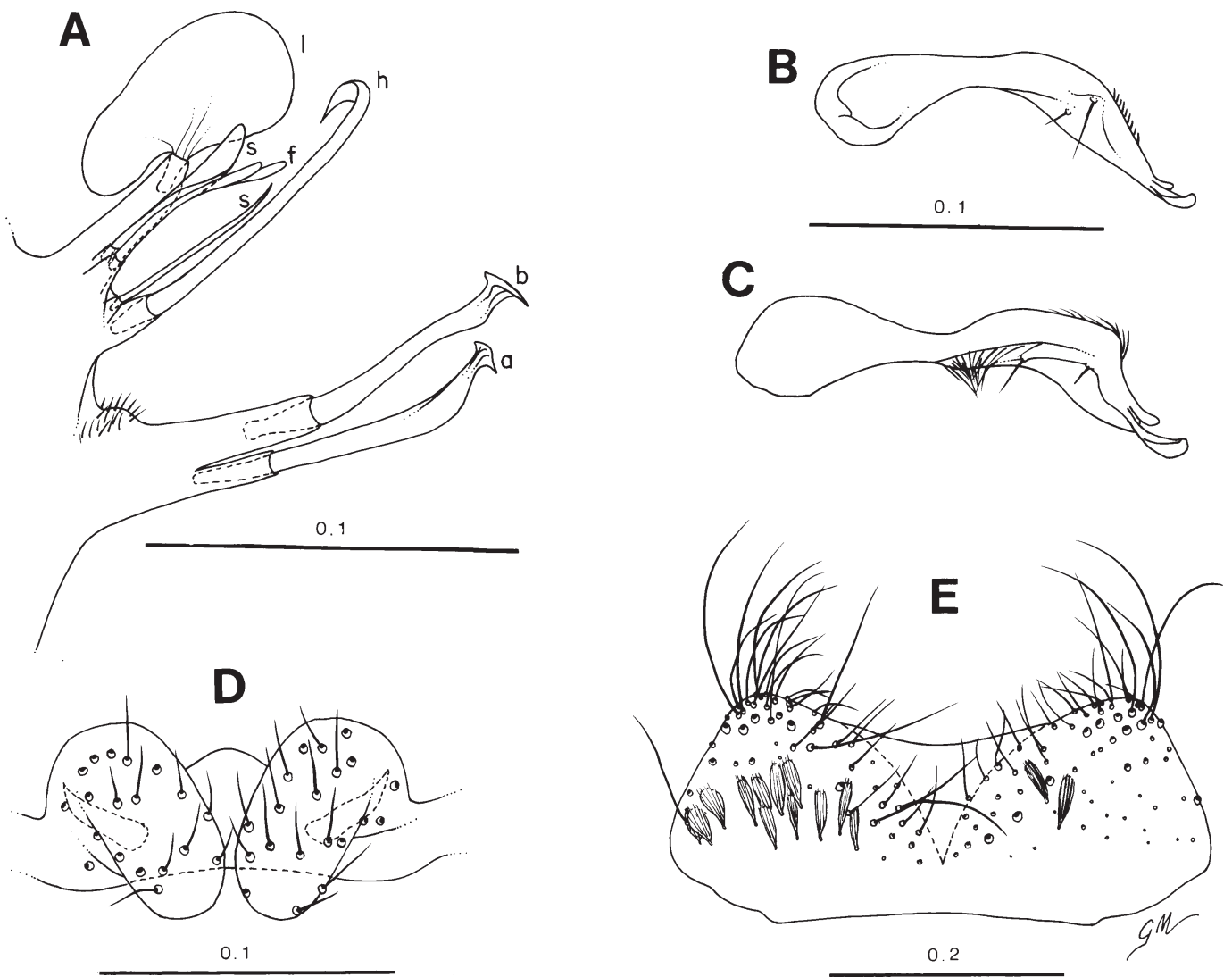

Fig. 2: male genitalia structures of Culex coppenamensis Form 2, Parque Nacional do Jaú, state of Amazonas, except for C. A: subapical lobe of gonocoxite showing both proximal and distal divisions in mesal aspect; B: gonostylus in lateral aspect; C: gonostylus in lateral aspect (French Guyana); D: tergum IX in dorsal aspect; E: tergum VIII in dorsal aspect. Scales in mm 
13 simple blades; $2-4$ cercal setae.

Material examined - Eighteen specimens ( 9 pinned adult males, 9 male genitalia on microscope slides). HOLOTYPE, male with dissected male genitalia on microscope slide, BRAZIL: state of São Paulo, Cananéia County, Itapitangui, Itapuan Farm, Atlantic Tropical System, 9 Feb 1991, 7:00 pm-8:00 pm, collected in Shannon trap inside tropical rain forest, Forattini et al. coll., deposited in the FSP-USP collection, under Acc. no. E-12529, São Paulo, Brazil. PARATYPES, same data as holotype except for 23 Feb 1981, 8:00 pm- 9:00 pm, 1 male, 1 male genitalia; 6 April 1981, 8:00 pm-9:00 pm, 1 male, 1 male genitalia; 10:00 pm- 11:00 pm, 1 male, 1 male genitalia; 20 April 1981, 7:00 pm-8:00 pm, 1 male, 1 male genitalia; CDC light trap, 9 April 1981, 6:00pm-midnight, 1 male, 1 male genitalia; Folha Larga Farm, 22 Nov. 1983, 6:00 pm-midnight, 1 male, 1 male genitalia; resting on vegetation, 20 March 1985, 2:00pm5:00pm, 1 male, 1 male genitalia; Pariquera-Açu County, Pariquera-Mirim suburb, resting on vegetation, 8 Aug. 1985, 2:00 pm-5:00 pm, 1 male, 1 male genitalia. Six paratypes are deposited in the FSP-USP collection and 2 in the Inpa Invertebrate Collection.

Etymology - The name alinkios, Greek for 'resembling, like', was chosen because $C x$. alinkios resembles $C x$. coppenamensis in adult and male genitalia characters.

Distribution and bionomics - Cx. alinkios is known from localities in the Ribeira Valley, Atlantic Tropical System, southeastern state of São Paulo, Brazil. Nothing is known about bionomics and medical importance of this new species.

Discussion - Cx. coppenamensis Forms 1 and 2 and $C x$. alinkios belong to the Bastagarius Subgroup of the Bastagarius Group of Sirivanakarn (1983) based on the following: proximal division of the subapical lobe of gonocoxite columnar, not clearly divided into two arms; lateral plate of phallosome with apical, lateral and ventral processes, ventral process arising at the same level of lateral process, hooklike, dorsolaterally bent, apical process broad, somewhat rectangular with flat, smooth apical margin, apical dorsal angle ending in an acute point and curved at dorsal edge. Cx. coppenamensis Forms 1 and 2 and $C x$. alinkios are morphologically similar to $C x$. coppenamensis s.s. in having the distal division of the subapical lobe of the gonocoxite divided into two arms, a short and broad arm and a strong, columnar arm, which arises from base of distal division (Figs 1A, B, 2A, 3B).
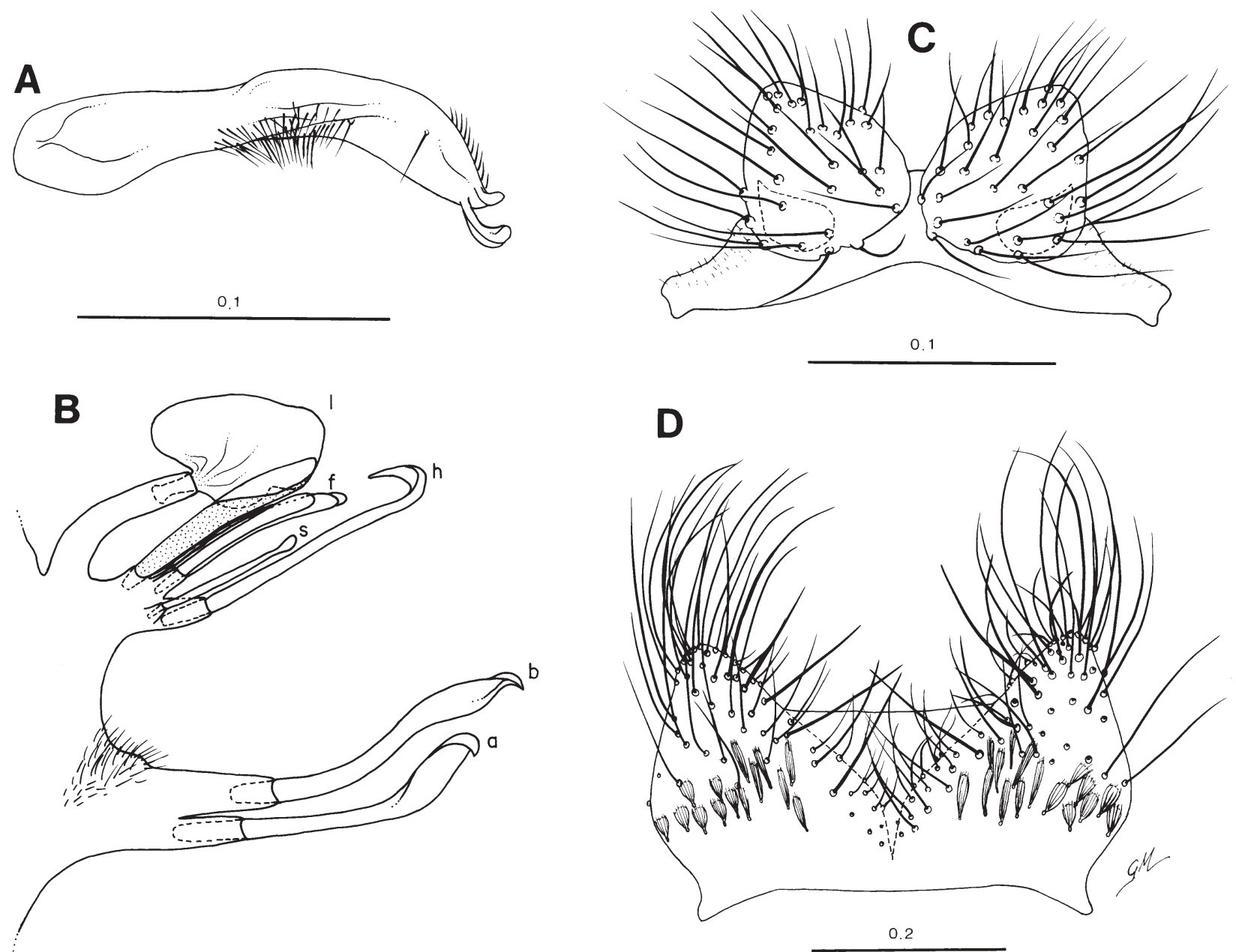

Fig. 3: male genitalia structures of Culex alinkios, holotype. A: gonostylus in lateral aspect; B: subapical lobe of gonocoxite showing both proximal and distal divisions in mesal aspect; C: tergum IX in dorsal aspect; D: tergum VIII in dorsal aspect. Scales in mm 
The distal arm has an enlarged, asymmetrical, foliform seta (1) inserted at the apex, the proximal arm has one long, strong, saberlike seta (s) arising from the apex on distal side and gonocoxite globose with a patch of long, strong setae (lsp) on lateral surface at level of subapical lobe (Fig. 1A). Unfortunately, except for the immatures of $C x$. coppenamensis (Bonne \& Bonne-Wepster 1925, Foote 1954), adult females and immature stages of $C x$. alinkios and $C x$. coppenamensis Forms 1 and 2 are unknown. Adult males are similar, and for accurate identification it is necessary to rely on characters of male genitalia. The diagnostic characters useful for distinguishing $C x$. coppenamensis s.s. from Cx. coppenamensis Forms 1 and 2 and $C x$. alinkios are not evident in the male genitalia drawing of Bonne and Bonne-Wepster's (1925). However, comparing the gonostylus and the distal division of the subapical lobe of the gonocoxite of $C x$. coppenamensis s. $s$. with those of $C x$. alinkios, $C x$. coppenamensis Forms 1 and Form 2, it seems to us that Form 2 corresponds with Cx. coppenamensis s.s. Systematic status of $C x$. coppenamensis Form 1 is not clear, and thus it is considered here as a morphological form similar to $C x$. coppenamensis s.s. Because $C x$. alinkios differs from the two Amazonian forms, and also from Cx. coppenamensis of Bonne and Bonne-Wepster's (1925), it is described as a new species.

Diagnostic characters discussed below are useful for distinguishing $C x$. coppenamensis Form 1 and 2 and $C x$. alinkios. Cx. coppenamensis Form 1 can be easily distinguished from $C x$. alinkios in having tergum VIII with a V-shaped emargination, separating two lateral lobes, which are somewhat round distally with scattered setae not forming a conspicuous distal setal group (Fig. 1F). Tergum VIII of $C x$. alinkios has a deep V-shaped emargination and exhibits two somewhat triangular lateral lobes with long, strong distal setae forming a conspicuous distal setal group (Fig. 3D). The gonocoxite of $C x$. coppenamensis Form 1 has 2-5 foliform setae at level of the subapical lobe on the tergomesal surface (Fig. 1B), which are absent in $C x$. alinkios and $C x$. coppenamensis Form 2. The gonostylus of the male genitalia of $C x$. coppenamensis Form 1 (Figs 1A, B) and Cx. alinkios (Fig. 3A) has a short and broad apical snout, and the subapical crest of spicules extends distally from widened part to the apex of the apical snout on ventral surface. In addition, the gonostylus of $C x$. coppenamensis Form 1 is shorter and the subapical part is broader than that of $C x$. alinkios. In contrast, $C x$. coppenamensis Form 2 has the apical snout long, the subapical crest of spicules is restricted to the widened part not reaching the apex of the apical snout (Figs 2B, C). In addition, Cx. coppenamensis Form 1 and 2 and $C x$. alinkios may be easily distinguished from each other by the distal arm of the distal division of the subapical lobe of the gonocoxite, which is markedly curved in Cx. alinkios (Fig. 3B), whereas it is straight in Cx. coppenamensis Form 1 and 2 (Figs 1A, B, 2A). The shape of the foliform seta (1) is also useful for distinguishing these forms (Figs 1A, B, 2A, 3B) also, seta 1 is striate at the base in $C x$. alinkios and $C x$. coppenamensis Form 2 (Figs 2A, 3B), whereas it is smooth in $C x$. coppenamensis Form 1 (Figs 1A, B).
Culex (Melanoconion) symbletos, $\mathrm{n} . \mathrm{sp}$.

\section{Cx. (Melanoconion) sp.1 of Pecor et al. (2000): 216}

(Fig. 4)

Male - Similar to $C x$. coppenamensis Form 1, but differing as follows. Head: antennal length $1.48-1.51 \mathrm{~mm}$ $($ mean $=1.50 \mathrm{~mm} \pm 0.01)(\mathrm{n}=4)$. Maxillary palpus length $1.90-2.11 \mathrm{~mm}(\mathrm{X}=1.97 \mathrm{~mm} \pm 0.12)(\mathrm{n}=3)$, extending beyond proboscis tip by length of palpomeres 4 and 5, palpomere 3 with three strong setae on outer apical surface. Thorax: Postpronotum with 3, 4 setae on posterodorsal margin. Pleural integument light brown to median brown, slightly darker on upper proepisternum, postspiracular area, prealar knob, lower portion of mesokatepisternum and mesepimeron; mesomeron and metapleura pale cream. Pleural setae: 7-11 upper proepisternal, 2-6 prealar, 7-9 upper mesokatepisternal, 7-9 lower mesokatepisternal and 6-8 upper mesepimeral. Wing: length $2.21-2.43 \mathrm{~mm}$ $(X=2.31 \mathrm{~mm} \pm 0.11)(\mathrm{n}=4)$; cell $\mathrm{R}_{2} 3.10-4.45$ of vein $\mathrm{R}_{2+3}$ $(X=3.64 \pm 0.58)(n=4) ;$ cell $M_{2} 0.68-0.74$ of cell $R_{2}$ (mean $=0.71 \pm 0.03)(n=4)$; subcosta intersects costa slightly proximal to furcation of $\mathrm{R}_{2+3}$. Abdomen: tergum III with basolateral patch of white scales; tergum VII not examined. Sternum II dark-scaled, sterna III-VI dark-scaled with basal bands of white scales; sternum VII not examined. Genitalia: tergal IX lobes as figured, lobes bearing a patch of long, strong setae inserted on outer apical area (Fig. 4E). Gonocoxite (Figs 4A, B) stocky, ovoid in shape, inner margin slightly concave; ventrolateral surface with strongly developed setae mixed with smaller setae, medial surface with sparse, small setae extending from base to the level of proximal division of subapical lobe, lateral surface without patch of setae (1sp) with 1, 2 small, slender setae at level of distal division of subapical lobe, dorsomedial margin with a patch of few, minute setae inserted proximally to subapical lobe (Fig. 4B), proximal part of ventrolateral surface with scales (Fig. 4A); subapical lobe clearly divided, divisions distinctly separate (Figs 4A, B); proximal division subdivided into two divergent arms, proximal arm shorter than distal arm, both arms bearing one long, apical, sinuous seta (setae a and $b$ ) at apex; distal division of subapical lobe with eight apical setae, one long hooked seta (h), one short saberlike seta (s) arising close to seta h, one relatively long saberlike seta (s), one slender, apically pointed seta (l) inserted at base of long saberlike seta (s), four narrow, appressed foliform setae (f) arising from distal side, most proximal seta (f) stronger than remaining setae f. Gonostylus (Figs 4A, B) slender, curved, widened on distal 0.5 in lateral view, tapering to apex, bearing an inconspicuous, subapical crest on ventral side extending from widened part to apical snout; apical snout elongate; gonostylar claw short, leaflike. Phallosome with lateral plate longer than aedeagal sclerite (Fig. 4C). Distal part of lateral plate with apical, lateral and ventral processes, apical process broad at base, apically expanded on ventral view, distal and dorsal border serrulate; ventral process strong, broad at base, tapering to apex, ending in a pointed tip; lateral process strong, pointed at apex, dorsolaterally directed; base of lateral plate with a short, strong dorsal process basally continuous with thickened margin of aedeagal 
sclerite; lateral plate not connected by dorsal aedeagal bridge. Paraproct crown (Fig. 4D) with a row of 12, 13 simple blades; tergum X (Fig. 4D) large, somewhat square in outline; basal plate (Fig. 4D) somewhat ovoid in outline.

Material examined - Eight specimens (4 pinned adult males, 4 dissected male genitalia on microscope slides, 1 wing mounted on microscope slide). HOLOTYPE, male with dissected genitalia on microscope slide, BRAZIL: state of Amazonas, Novo Airão County, Parque Nacional do Jaú, Carabinani River (1 ${ }^{\circ} 59^{\prime}$ 'S and $\left.61^{\circ} 32^{\prime} \mathrm{W}\right), 29$ July 1995, collected in Shannon trap, 6:00 pm-8:00 pm inside primary tropical rain forest, Hutchings and Sallum coll., deposited in the INPA Invertebrate Collection, Manaus, Amazonas, Brazil. PARATYPES, same collection date of

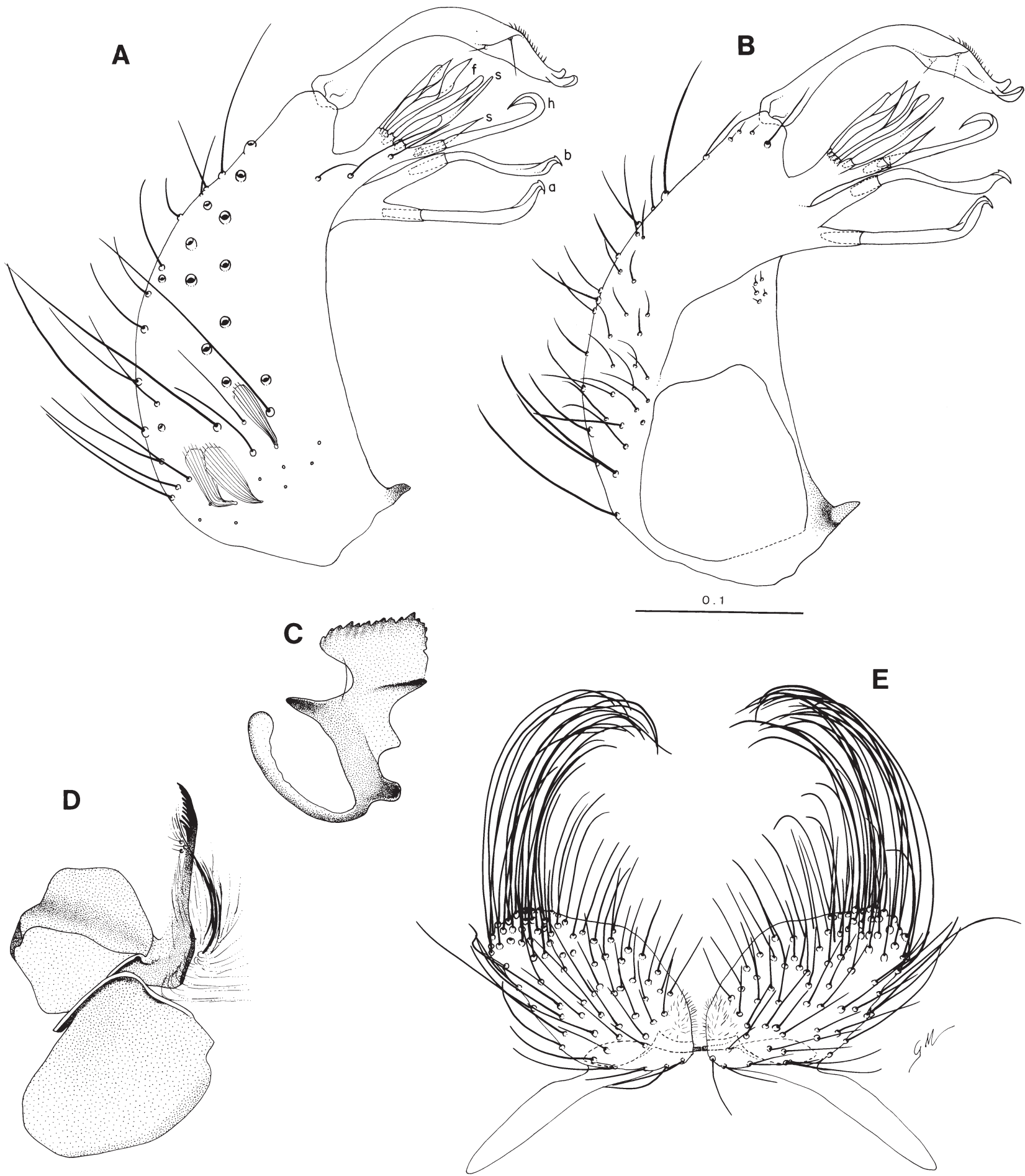

Fig. 4: male genitalia structures of Culex symbletos, holotype. A: gonocoxite and gonostylus in lateral aspect; B: gonocoxite in mesal aspect; C: lateral plate and aedeagal sclerite in lateral aspect; D: proctiger; E: tergum IX in dorsal aspect. Scales in mm 
holotype except for Miratuca River (1047'2"S and 61 499'1'W), 26-27 July 1995, collected in UV light trap, 6:00 pm-6:00 am, inside primary forest, RW Hutchings coll., 1 male, 1 male genitalia; 28-29 July 1995, 1 male, 1 male genitalia, 1 wing mounted on microscope slide; 23 July 1995, 4:00 pm-4:30 pm, Sallum \& Hutchings coll., resting on vegetation inside primary tropical rain forest, 1 male, 1 male genitalia. One paratype is deposited in the Inpa Invertebrate Collection, and 2 paratypes in the FSP-USP Collection. OTHER MATERIAL: HOLOTYPE of $C x$. mesodenticulatus, adult male with dissected male genitalia on microscope slide, PANAMA: Almirante, Bocas del Toro (USNM).

Etymology - The name symbletos, Greek for 'comparable', was chosen because $C x$. symbletos is morphologically comparable to $C x$. mesodenticulatus.

Distribution and bionomics - Cx. symbletos is know from the type locality in the Parque Nacional do Jaú, Novo Airão County, Amazonas, Brazil, and Iquitos, Peru (Pecor et al. 2000). Nothing is known about the bionomics and medical importance of $C x$. symbletos.

Discussion - Cx. symbletos belongs to the Inhibitator Subgroup within the classification of Melanoconion proposed by Sirivanakarn (1983) based on: lateral plate of phallosome with ventral, lateral and apical processes, apical process well developed, broad, prominent with a row of distinct teeth on distal margin, ventral process well developed, pointed at apex, lateral process small, arising at the same level as the ventral process, and gonostylus not strongly modified. Cx. symbletos is markedly morphologically similar to $C x$. mesodenticulatus in having the IXth tergal lobes somewhat ovoid in outline, covered with stiff setae which become longer, stronger and curved from base to apex of each lobe forming a patch of setae on outer apical area (Fig. 4E). Cx. symbletos can be separated from $C x$. mesodenticulatus by the absence of a long, columnar arm, with foliform setae $\mathrm{f}$ inserted at the apex, which arises from the base at distal side of distal division of subapical lobe of gonocoxite. In Cx. symbletos, foliform setae $\mathrm{f}$ arise from the distal side of the distal division (Figs 4A, B). Cx. symbletos is also similar to Cx. albinensis Bonne-Wepster and Bonne, from which it can be distinguished by the shape of the IXth tergal lobe and presence of an outer apical setal group. In Cx. albinensis, the IXth tergal lobe has sparse setae, which are shorter than those of Cx. mesodenticulatus and Cx. symbletos, and not form an apical setal group of long, strong setae. In addition, seta 1 is slender and pointed in Cx. mesodenticulatus and Cx. symbletos (Fig. 4A), whereas it is relatively broad and somewhat spoon-shaped in $C x$. albinensis.

\section{ACKNOWLEDGMENTS}

To Roger W Hutchings (Inpa - CPEC), and two anonymous reviewers for their valuable suggestions and for providing helpful comments to improve the present manuscript.

\section{REFERENCES}

Belkin JN 1968. Mosquito studies (Diptera: Culicidae). IX. The type specimen of New World mosquitoes in European museums. Contrib Amer Entomol Inst 3: 1-69.

Bonne C, Bonne-Wepster J 1925. Mosquitoes of Surinam. A Study on Neotropical Mosquitoes, Uitgave van Het Instituut, Druk de Bussy, Amsterdam.

Foote RH 1954. The larvae and pupae of the mosquitoes belonging to the Culex subgenera Melanoconion and Mochlostyrax. US Dept Agric Tech Bull 1091: 1-126.

Pecor JE, Jones J, Turell MJ, Fernandez R, Carbajal F, O'Guinn M, Sardalis M, Watts D, Zyzak M, Calampa C, Klein TA 2000. Annotated checklist of the mosquito species encountered during arboviral studies in Iquitos, Peru (Diptera: Culicidae). J Amer Mosq Control Assoc 16: 210218.

Pecor JE, Mallampalli VL, Harbach RE, Peyton EL 1992. Cata$\log$ and illustrated review of the subgenus Melanoconion of Culex (Diptera: Culicidae). Contrib Amer Entomol Inst 27: $1-228$.

Sirivanakarn S 1983. A review of the systematics and a proposed scheme of internal classification of the New World subgenus Melanoconion of Culex (Diptera: Culicidae). Mosq Syst (1982) 14: 265-333. 